Ionela GAVRIL $\breve{A-P A V E N ~}$

Ioan BELE

\title{
3.6. DEVELOPING A GROWTH POLE: THEORY AND REALITY
}

\section{Summary}

In this article there will be presented the concept of growth pole and analysed also the necessity of creating such growth pole at regional level. There will be presented different opinions related to this concept and also examples of growth poles that are functioning and which can be considered as reference point for developing growth poles in Romanian regions. In the second part of the article we will present the benefits of creating a growth pole in the Center Region that will include two cities, respectively Alba Iulia and Sebeş.

Keywords: growth pole, economic development, regional development, sustainability, industrial and logistic parks

\section{Introduction}

Considering the present evolution of regional development all over the world, there is a concept that is pointed out from the experience of different regions, namely growth pole. As a general and exhaustive definition, based on the analyse of the definitions given by different experts in the field, a growth pole is: (1) a point of economic growth; (2) a central location of economic activity; (3) a point where economic growth starts and spreads to surrounding areas; (4) an urban location where economic activity ignites growth and better quality of life in the urban periphery. This is a general definition that supposes a strong relation between growth poles, economic growth and urbanization, as well as potential interaction effects that occur.

\section{Literature review}

The concept of growth pole was used for the first time by Francois Peroux in 1949. His work focused on this topic analysed especially the economic aspects of the growth poles. But the opinion of the researchers in this field regarding the growth poles are not in consensus, especially if there is considered the activity area of the authors. So there are different points of view regarding the growth poles coming from economists, geography experts or territory development experts. The intuitive notion of growth poles identifies a growth pole as an industry or perhaps a group of companies within an industry. At an extreme a growth pole might be a single firm or it might be a group of industries. Perroux, however, defined growth poles in terms of what he called abstract economic space. In his opinion, this abstract economic space can be of three types: an economic plan, a field or force of influences and a homogenous aggregate. 
Analysing the regions developed all over the world, we have to consider the concept of growth pole as one of the key elements that contributed to the development of these regions. According to the Oxford Dictionary, poles are usually urban locations, benefiting from agglomeration economies, and should interact with surrounding areas spreading prosperity from the core to the periphery. Observation of naturally occurring growth poles has inclined planners to create new growth poles; the best-known attempt at creating growth poles took place in the Mezzogiorno (south) of Italy, with industrial complexes planned at Taranto and Bari. Such artificially created growth poles, as in France, have not stimulated regional development as much as was hoped. Monsted (1974) and Parr (1999) agree that the widespread use of the growth pole concept is reflected in the number of conferences and publications on the subject, as well as the apparent positive outcome of its application in developed countries in Western Europe (Mandala Gantsho, 2008).

The main idea of the growth poles is that economic development or growth, is not uniform over an entire region, but instead takes place around a specific pole. This pole is often characterized by a key industry around which linked industries develop, mainly through direct and indirect effects. The expansion of this key industry implies the expansion of output, employment, related investments, as well as new technologies and new industrial sectors. Because of scale and agglomeration economies near the growth pole, regional development is unbalanced. Transportation, especially transport terminals, can play a significant role in such a process. The more dependant or related an activity is to transportation, the more likely and strong this relationship.

Figure 1. Representation of growth pole

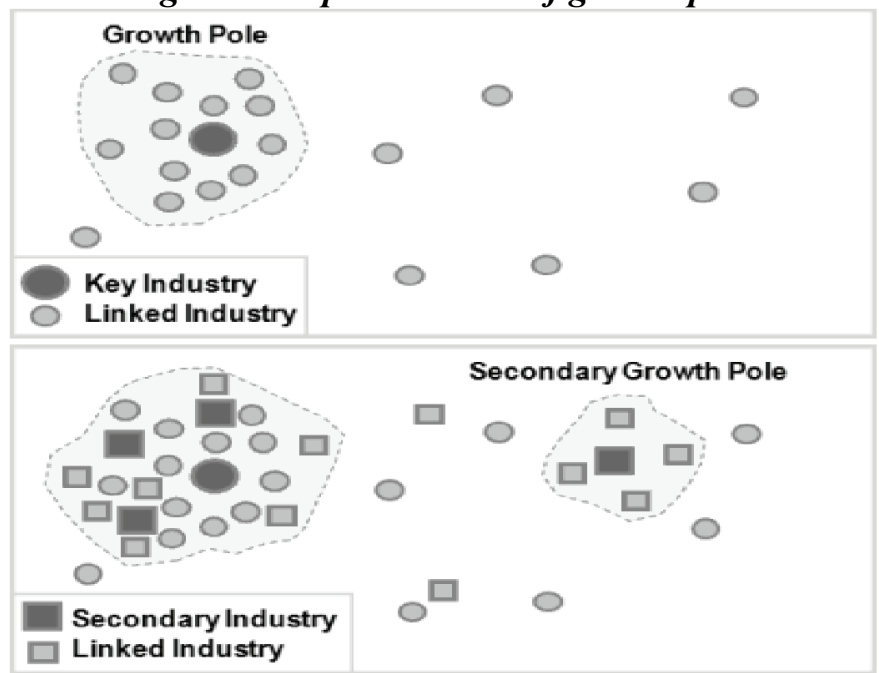

Source: http://people.hofstra.edu/geotrans/eng/ch2en/conc2en/growthpoles.html

At a later stage, the emergence of a secondary growth pole is possible, mainly if a secondary industrial sector emerges with its own linked industries (This is the main idea developed in The Geography of Transport Systems, formally known as Transport Geography on the Web, which represents a project that has been ongoing since 1998, Project Director Dr. Jean-Paul Rodrigue, Professor with the Dept. of Global Studies \& Geography, Hofstra University, Hempstead, New York, USA). 
Regional development based on growth pole strategy became popular in developing countries in the 1960's, mostly in Latin American Countries, with national governments filled with optimism about its benefits for economic growth and social progress (Angotti, 1998). Ironically by the 1970's, the interest in the growth pole concept in developing countries had dwindled, after its application failed to record the anticipated outcome (Gilbert, 1974; Conroy, 1973; Moseley, 1973).

The discussion on definitions of the growth pole and literature review identified five key factors as influencing growth at these centers. Firstly, there should be a proven economic base, which can sustain growth through exploitation of local natural resources. Raw materials like minerals whose exploitation might trigger a chain reaction as more economic activities move in to take advantage of the natural resource base (Manyanhaire, Mhishi, Svotwa and Sithole, 2009). This gives space to a second characteristic of the existence of high potential for the development of substantial forward and backward linkages with the surrounding hinterlands. The third factor has to give attention to the availability of adequate resources, both physical and human to sustainably feed the growth pole. These centers also have the potential to facilitate the process of industrial decentralization by providing alternative but viable investment opportunities. Lastly, they are established in places where there is already some potential for economic growth and the role of government being to stimulate and support this potential until the process of economic growth becomes sustainable and equitable.

In Romania, the necessity for developing growth centers is included in the Operational Regional Program for 2007-2013 and it is based on regional development law (Law no. 151/1998), modified through Law no. 315/2004, respecting the European Commission Regulation no. 1059/2003. So, according to these regulations in order to have an equilibrium development, the cities that are the county residence should be used as social and economic development engines, representing in fact the definition of growth poles. In the same time, the effects of the agglomeration of small and medium cities from the preponderant rural areas can be used if these effects were proven. The objective of the Operational Regional Program 2007-2013 is to support an equilibrate economic and social territorial development, corresponding to the regional needs and resources, using the growth poles and developing the infrastructure and the business environment for increasing the attractiveness of the Romanian regions for investors, tourisms and also for their inhabitants.

So, considering all these aspects, as it follows we will try to present, from our point of view the idea and also the necessity of creating a growth pole in the region Alba and Hunedoara County, concentrated on the present cities of Alba Iulia and Sebeş.

\section{Growth pole Alba Iulia - Sebeş - Concept description}

Alba Iulia - Sebeş is an entity that does not exist today but, certainly there will be in the future. The sooner this entity will be establish the sooner the effects for both Alba Iulia and the Sebeş will be visible. There is a window of time about one year, very short, to convince the two cities' population of the need of their fusion with the preservation of their heritage. To these two cities it has to be added the villages of 
Ciugud and Pianu in the minimal variant, and in the optimal variant the villages Ighiu, Sântimbru, Cricău, Galda de Jos, Stremţ, Mihalţ, Daia Română and City Teiuş.

This fusion is very important both for its future localities component but also for the future of Alba County, which in the perspective of 2013 will have profound transformations, being possible to disappear in one alternative, or to become an administrative unit of an administrative region of which center will be in a bigger city in another alternative, or to become a coagulation center of a region with the capital in this area in an optimum alternative (optimum, from our point of view). To accomplish such a goal there is need to involve all stakeholders in the area, to harmonize their individual aims and to show them that this is the right to act in this period and also the right thing to do for developing this community, community to which they belong also. Description of present situation

The thirteenth administrative units that will be the component elements of the new growth pole that we are proposing are particular through the following statistic data: (1) Alba Iulia has a surface of 104 square $\mathrm{km}$ and a population of 68,181 inhabitants at July $1^{\text {st }} 2010$ being rank as $37^{\text {th }}$ place in the 41 capitals of the Romanian counties, being surpassed even by cities that are not county capitals such as Hunedoara and Bârlad. The city evolution after 1990 is characterized through the following important data: at the census in 1992 the city had a population of 71,168 inhabitants that decreases to 66,404 inhabitants at the census in 2002 and recorded a minimum of 66,000 inhabitants in 2006, since the population started to increase slowly to the level of 68,181 inhabitants. Alba Iulia has been ranked as 39 from the 41 county capitals until appeared Ilfov County, which shows that Alba Iulia as county center did not succeed in polarizing the county as it could be, the report between the county center and the following city in the county being $1 / 2.3$; (2) Sebeş has a surface of 116 square $\mathrm{km}$ and a population of 28,911 inhabitants at July $1^{\text {st }} 2010$ being rank as $80^{\text {th }}$ place in the cities of the Romania. The population of Sebeş was in 1992 of 29,754 inhabitants decreasing to 27,754 inhabitants in 2002 and recording the lowest level in 2006 of 27,000 inhabitants since the population started to increase slowly to the level of 28,911 inhabitants; (3) Village Vinţul de Jos has at July $1^{\text {st }} 2010$ a population of 5,388 inhabitants and a surface of 85 square km; (4) Village Ciugud has at July $1^{\text {st }} 2010$ a population of 2,817 inhabitants and a surface of 44 square $\mathrm{km}$; (5) Village Ighiu has at July $1^{\text {st }} 2010$ a population of 6,567 inhabitants and a surface of 128 square $\mathrm{km}$; (6) Village Sântimbru has at July $1^{\text {st }} 2010$ a population of 2,981 inhabitants and a surface of 44 square km; (7) Village Galda de Jos has at July $1^{\text {st }} 2010$ a population of 4,852 inhabitants and a surface of 90 square km; (8) Village Cricău has at July $1^{\text {st }} 2010$ a population of 2,190 inhabitants and a surface of 51 square $\mathrm{km}$; (9) Village Stremţ has at July $1^{\text {st }} 2010$ a population of 2,583 inhabitants and a surface of 69 square $\mathrm{km}$; (10) Village Pianu has at July $1^{\text {st }} 2010$ a population of 3,469 inhabitants and a surface of 115 square $\mathrm{km}$; (11) Village Mihalţ has at July $1^{\text {st }} 2010$ a population of 3,429 inhabitants and a surface of 65 square km; (12) City Teiuş has at July $1^{\text {st }} 2010$ a population of 7,458 inhabitants and a surface of 45 square $\mathrm{km}$; (13) Village Daia Română has at July $1^{\text {st }} 2010$ a population of 3,098 inhabitants and a surface of 30 square $\mathrm{km}$. 


\section{Growth pole Alba Iulia - Sebeş - Solution for regional development}

So, considering all these statistic data the total surface of the future growth pole of Alba Iulia - Sebeş will be of 986 square $\mathrm{km}$ and the population of 141,900 inhabitants. The new city will be ranked on $18^{\text {th }}$ place after Târgu Mureş and before cities like: Baia Mara, Botoşani, Satu Mare, Piatra Neamţ, Râmnicu Vâlcea, Suceava, Drobeta Turnu-Severin, Târgovişte, Târgu Jiu, Focşani, Tulcea, Reşiţa, Hunedoara, Bistriţa şi Deva.

Considering the new administration structure will need 50 local counselors less, 5 mayors less and 5 vice-mayors less also, that will led also to savings to the local budget. Considering the other earnings from this project we can point out the following: (1) creating a growth pole at supra-regional level with increased attractively for Alba and Hunedoara Counties, which in 2030 will have approximately 160,000 inhabitants in the average alternative slowing the population decreasing process in Alba County; (2) access to A1 highway and $4^{\text {th }}$ European Road Corridor; (3) access to $9^{\text {th }}$ European Railway Corridor; (4) possibility of modernizing the railway stations from Coşlariu and Vinţu de Jos for freight and passengers; (5) possibility of developing at the intersection of A1 highway with the express road Sebeş - Alba Iulia - Turda a large logistic park for Central Transilvania in the area of Cluj-Napoca, Târgu Mureş and Bistriţa due to the fact that the A3 highway will be finished, at present speed of building, in approximately 20 years; (6) building the airport Alba Hunedoara at Pianu de Jos or Şibot - Aurel Vlaicu; (7) developing as industrial park the area Sebeş - Vinţul de Jos; (8) developing as industrial par also the area of Galda de Jos - Oiejdea - Sântimbru; (9) developing as residential areas the villages Ighiu, Cricău, Ciugud and Vinţul de Jos; (10) developing as recreation areas the following locations: Ighiel, Galda de Sus - Poiana Gălzii, Pâclişa - Pârâul lui Mihai, Pianul de Sus - Strungari - Recea, Mamut Mountain, Țelna - Cricău - Piatra Crăivii; (11) developing the superior education programs in Sebeş for military units; (12) cultural development of the future city by establishing the Drama Theater in Lancrăm, the Opera and Symphonic Orchestra in Alba Iulia; (13) increasing the prices of real estate between $30 \%$ and $100 \%$ depending on the area; (14) creating approximately 7,000 new jobs in the industrial and logistic parks and over 1,000 new jobs in commerce and services; (15) attracting foreign direct investment in industrial and logistic parks in Sebeş, Coşlariu and Vinţu de Jos; (16) strong polarization of Alba territory beyond Aiud, Blaj, Cugir, Zlatna from Alba County and Geoagiu - Orăştie from Hunedoara County and reviving the areas of Trascău (Zlatna Town and villages Râmeţ, Ponor, Mogoş, Întregalde, Meteş, Almaşu Mare) precum şi a celei mai disadvantaged area from the Center Region and the Secaşelor Plateau including the villages: Berghin, Ohaba, Roşia de Secaş, Şpring, Doştat; (17) developing a strong commercial area between Alba Iulia and Sebeş at Lancrăm - Trei Poduri; (18) developing together with "1 Decembrie 1918" University of Alba Iulia and the Chamber of Commerce and Industry of the Alba County and exhibition complex; (19) developing a techno pole in the area of Refractara in Alba Iulia. 


\section{Conclusions regarding the organization and functioning of the growth pole}

The new city will be organized administratively on sectors with elected mayors, vicemayors and counsellors of the sector, each sector having at least 5,000 inhabitants and a surface of minimum 100 square $\mathrm{km}$. From our point of view, there could be established the following sectors: (1) Sebeş Sector with a surface of 116 square $\mathrm{km}$ and a population of 28,611 inhabitants; (2) Alba Iulia Sector with a surface of 104 square $\mathrm{km}$ and a population of 68,161 inhabitants; (3) Ighiu Sector with a surface of 128 square km and a population of 6,567 inhabitants; (4) Galda de Jos - Cricău Sector with a surface of 141 square $\mathrm{km}$ and a population of 6,757 inhabitants; (5) Teiuş - Stremţ Sector with a surface of 114 square $\mathrm{km}$ and a population of 10,041 inhabitants; (6) Sântimbru - Mihalţ Sector with a surface of 109 square $\mathrm{km}$ and a population of 6,410 inhabitants; (7) Ciugud - Daia Română Sector with a surface of 74 square km and a population of 5,915 inhabitants; (8) Vinţul de Jos - Pianu Sector with a surface of 116 square $\mathrm{km}$ and a population of 28,611 inhabitants.

Regarding the management of the new city, it will be needed of a Common Hall elected with a representation of one counsellor to 5,000 inhabitants with vote right, with circumscriptions organized on sectors. There will be also the 8 mayors of the sectors and the mayor of the new city elected directly, which will have also the status of a counsellor. The City Hall and the Sectors Hall will have proper administrative structure which will be dimensioned related to the attribution given by law, by city status and the decisions of the Common Hall. In order to harmonize all interests, including the political one, there is necessary to form a supporting committee for developing the concept, which will include experts from all fields of activity.

Considering the separation of attributes and tasks in the future administrative organization, the city and the sectors will have distinct responsibilities. As a proposal regarding these attributions, they could be separated as it follows:

a) For the city: (1) territory organization of the city: cadastre, city planning, localities network, city road, water network, sewerage, electricity, gas, investments and projects; (2) population and housing: population evidence on inhabitants and localities, marriages and divorces, unemployment, young and old population, population's incomes, policy for housing; (3) economic and territorial development of the city: the Chamber of Commerce and Industry of the City, city marketing, administration of the industrial and logistic parks, cluster development and monitoring, investment attraction, services for companies, Chamber for Agriculture of the City, City Forest Hall; (4) supporting the educational system through high-schools, professional schools, universities, research, innovation, competition with other cities, culture and local heritage, sport; (5) services for population: health, social assistance, transportation between localities, recreation activities; (6) urban: person's safety, quality of housing, air, water, soil and subsoil pollution, social groups' safety, local justice; (7) city budget: taxes and payments, collecting, monitoring, planning and execution of the sectors' budgets.

b) For the sectors: (1) organizing the territory of the sector: urban planning, detailed planning, authorizations, vacation houses, discipline in constructions; (2) services of population evidence: marriages and divorces, unemployment, young population, old population, population's incomes, policy for housing; (3) road maintenance, local 
transportation, sector network of water and sewerage maintenance; (4) education: nurseries, kindergartens, gymnasium education, medical services for family, medical center, sector library, cultural centers and sectors clubs; (5) budget: city and sector tax collector, execution, control and report of the payments, approvals of payments; (6) urgent, risks and natural disaster situations' management; (7) administration of forests in the property of sectors hall and the citizen according to the legal norms and administration of sectors' fields.

\section{References}

1. Angotti, T. (1998): Ciudad Guayana: From Growth Pole to Metropolis, Central Planning to Participation, Paper Presented at the Latin American Studies Association Conference, Chicago, September 1998.

2. Conroy, M. E. (1973): On the rejection of 'growth center' policy in Latin American regional development planning, Land Economics, vol 49: 317-380.

3. Darwent, D. (1969): Growth poles and growth centers in regional planning-a review, Environment and Planning, vol. 1, pp. 5-32.

4. Gantsho, M. S. V. (2008): Cities as Growth Poles Implications for Rural Development, Annual Meetings Seminar held in Maputo, Mozambique, http://www.afdb.org/fileadmin/uploads/afdb/Documents/Knowledge/30732302-EN-DRMANDLA-S.V-GANTSHO-CITIES-AS-GROWTH-POLES.PDF

5. Gilbert, A. (1974): Growth Poles: the instant solution to regional problems?, In: R.S. Thoman (ed.): Proceedings of the Commission on Regional Aspects of Development. Vol. 1: Methodology and case Studies: 111-128. Toronto: Allister Publishing.

6. Manyanhaire, I.O. Mhishi, B Svotwa, E. and Sithole, N. (2009): Growth Points or Declining Points? A Case of Magunje Growth Point in Mashonaland West Province of Zimbabwe, Journal of Sustainable Development in Africa, Volume 10, No.4, 2009, pages 506-519.

7. Manyanhaire, I.O., Rwafa, R., Mutangadura, J. (2011): A Theoretical Overview of the Growth Centre Strategy: Perspectives for Reengineering the Concept in Zimbabwe, Journal of Sustainable Development in Africa, Volume 13, No.4, ISSN: 1520-5509.

8. Mayhew, S.: Dictionary of Geography, Oxford University Press, http://www.answers.com/library/Geographical+Dictionary-cid-15086979

9. Monsted, M. (1974): François Perroux's Theory of "Growth Pole" and "Development Pole": A Critique, Antipode, vol. 6, Issue 2: 106-113, July

10. Moseley, M. J. (1973), Growth center: a shibboleth?, Area, vol. 5:143-150.

11. Parr, J. B. (1999): Growth Pole Strategies in Regional Economic Planning: A Retrospective View. Part 1: Origins and Advocacy, Urban Studies, Vol. 36(7): 1195-1215.

12. Rodrigue, J-P.: The Geography of Transport Systems, Dept. of Global Studies \& Geography, Hofstra University, Hempstead, New York, USA http://people.hofstra.edu/geotrans/eng/ch2en/conc2en/growthpoles.html 